\title{
KNOWLEDGE REGARDING TRANSMISSION OF HEPATITIS B INFECTION AMONG HBSAg POSITIVE PATIENTS IN A TERTIARY CARE HOSPITAL
}

\author{
N. Premaletha ${ }^{1}$
}

1 Professor and HOD, Department of Gastroenterology, Government Medical College, Kottayam, Kerala.

\begin{tabular}{l}
\hline ABSTRACT \\
BACKGROUND \\
Chronic hepatitis is easily preventable by increasing awareness in the community. A significant gap in knowledge and the public \\
health issues due to hepatitis B is evident in Kerala and there are limited studies regarding these. Hence, the objective of the study is \\
to assess the knowledge of the patients regarding transmission of hepatitis B infection.
\end{tabular}

\section{MATERIALS AND METHODS}

It is a cross-sectional descriptive study. Respondents were identified from the patients (HBsAg positive) attending OP in the Gastroenterology Department of Medical College, Thiruvananthapuram and 391 such cases were selected.

\section{RESULTS}

Hepatitis B was heard by about 59 of the patients. When enquired about whether they know about organ affected by the HBV virus, only 48 percent answered 'Yes,' out of these 94 percent answered correctly. When enquired about whether they know about how to spread the virus, about 53 percent answered 'Yes,' out of these only 12 percent answered correctly. It was evident from the analysis that even the highly educated and professionally occupied category did not know the correct route of transmission of the virus. Majority of the respondents were not reporting media as a source of knowledge. Health providers and Government should take necessary steps in creating awareness regarding the HBV through media, so that people can easily get the message. Even the educated does not know the difference between hepatitis A and B and majority have not heard about other virus like Hepatitis C.

\section{CONCLUSION}

It can be concluded from the study that there exists disparity in educational group regarding knowledge on HBV, which should be addressed for prevention activities.

\section{KEYWORDS}

Hepatitis B, Knowledge, Transmission, Kerala.

HOW TO CITE THIS ARTICLE: Premaletha N. Knowledge regarding transmission of hepatitis B infection among HbsAg positive patients in a tertiary care hospital. J. Evolution Med. Dent. Sci. 2018;7(05):632-636, DOI: 10.14260/jemds/2018/143

\section{BACKGROUND}

Hepatitis B is one of the most common infectious diseases of the world. HBV-related chronic liver disease and cirrhosis of the liver and primary hepatocellular carcinoma associated with HBV infection is the 10th leading cause of death worldwide (WHO, 2008; Lavanchy, 2004).[1],[2] Hepatitis B is a major health problem in India. Based on the prevalence of Hepatitis B carrier state in the general population, countries are classified as having high ( $8 \%$ or more), intermediate $(2 \%$ $7 \%$ ) or low (less than 2\%) HBV endemicity. India has intermediate endemicity of Hepatitis B with Hepatitis B surface antigen (HBsAg) prevalence between $2 \%$ and $10 \%$ among populations studied. Roughly, a tenth of the total global load resides in India (Alter, 2003; Ganem, 2004).[3] The number of HBsAg carriers in India has been estimated to be over 400 million. According to WHO in India, of the 25 million infants born every year over one million run the lifetime risk of developing chronic HBV infection. Estimates indicate that annually over 100,000 Indians die due to illness related with HBV infection.

'Financial or Other Competing Interest': None.

Submission 18-07-2017, Peer Review 11-11-2017,

Acceptance 19-12-2017, Published 29-01-2018.

Corresponding Author:

Dr. N. Premaletha,

TC/2/379(6), 'Deepthi' Doctor's Garden, Ulloor,

Medical College P. O, Trivandrum-695011, Kerala.

E-mail: drpremalathasunil@gmail.com

DOI: $10.14260 / \mathrm{jemds} / 2018 / 143$
All cases of viral hepatitis are caused by one of the five viral agents; Hepatitis A virus, Hepatitis B virus, Hepatitis C virus, HBV associated delta agent or HDV and Hepatitis E virus. Other transfusion transmitted agents, e.g. 'Hepatitis G' and 'TT virus' have been isolated from cases of viral hepatitis, but were not found to influence the natural course of the illness and recovery (Bhat, 2009). Among the viral infections, $\mathrm{HBV}$ is more infective than the other viruses. Detection of hepatitis $B$ surface antigen (HBsAg) in blood is diagnostic for infection with HBV.

The hepatitis viruses have mainly two modes of transmission; parenteral and enteric. Hepatitis B virus is spread by mucous membrane contact with blood or other infectious body fluids such as saliva, semen and vaginal fluid. Hepatitis B virus is not spread by air, food or water. Transmission from an infected mother to her baby usually happens at the time the baby is born. HBV is able to remain on any surface it comes into contact with for about a week, e.g. table-tops, razor blades, blood stains without losing infectivity. But it does not cross the skin or the mucous membrane barrier. Some break in this barrier, which can be minimal and insignificant, is required for transmission. HBV is a large virus and does not cross the placenta, hence it cannot infect the foetus unless there have been breaks in the maternal-foetal barrier, e.g. via amniocentesis. Still, pregnant women who are infected with HBV can transmit their disease to their babies at birth. If not vaccinated at birth, many of these babies develop lifelong HBV infections, and many develop liver failure or liver cancer later in life. Sexual intercourse with multiple partners 
or with persons who have multiple partners can be dangerous. It is a fact that most infected people look perfectly healthy and have no symptoms of disease, yet may be highly infectious.

However, most of India's carrier pool is established in early childhood, predominantly by horizontal spread due to crowded living conditions and poor hygiene. India has intermediate endemicity of Hepatitis B with Hepatitis B surface antigen (HBsAg) prevalence of $4 \%$. It is estimated that there are 12.5 million HCV carriers in our country, and at least a quarter of them are likely to develop chronic liver disease in the next 10 to 15 years. In community prevalence study from Tamilnadu (Kurien et al, 2005),[4] the HBsAg prevalence was 5.7 percent with 23.5 percent of these having positive HB eantigen.

In contrast low prevalence of HBsAg is reported from various studies in Kerala. Jayaprakash et al (1983) [5] in their study of 8085 volunteer donors attending the blood bank at SCTIMST in Kerala screened for hepatitis B surface antigen (HBsAg) carrier state by counter immunoelectrophoresis found that $103(1.27 \%)$ were HBsAg positive. Sandesh et al $(2006)^{[6]}$ compared the prevalence of hepatitis B and C in normal populations and risk group infections in north Kerala. They found that the prevalence of Hepatitis $B$ and $C$ in the normal population of Calicut is $0.5 \%$ and $0.2 \%$. But a high prevalence among risk group was found. Among the IV drug abusers $2.7 \%$ were HBsAg positive and $51.9 \%$ were positive for anti-HCV. In commercial sex workers, $3.47 \%$ were $\mathrm{HBsAg}$ positive and $2.6 \%$ were anti-HCV positive. In male homosexuals, $4.5 \%$ were HBsAg positive and $3.4 \%$ were antiHCV positive. Limited studies in Kerala regarding HBV, especially knowledge about the diseases and route of transmission is the scope of the present study.

Assessing the knowledge and practices of the patient regarding transmission of hepatitis $\mathrm{B}$ and $\mathrm{C}$ infection, Afzal and Basheer (2009) ${ }^{[7]}$ found that knowledge and practices regarding spread of Hepatitis B and C were poor. Singh and Jain et al (2011) ${ }^{[8]}$ reported that there was lack of awareness about Hepatitis B, its route of transmission and modes of prevention even among the medical students entering into the profession and all these students were not vaccinated against Hepatitis B, which makes them vulnerable to the disease.

Chronic hepatitis is easily preventable by increasing awareness in the community. Effective vaccine against HBV has been available since the 1980 s, but parental and early life exposure continues to be a major source of infection in much of the developing world because of the limited resources.

In these backgrounds, it is proposing to undertake a study aimed at understanding the knowledge of HBV among patients attending the OP in Gastroenterology unit of the Medical College. The implementation of a comprehensive public health response to hepatitis B in Kerala is urgently required to reduce the increasing burden of hepatitis B infection on the health system and the community. A significant gap in knowledge of the diseases and the public health issues due to hepatitis B is evident in Kerala, as there are limited studies regarding these. Hence, it is necessary in understanding the knowledge of the disease among patients which will in turn help to understand how people infect with hepatitis. Hence, the objective of the study is to assess the knowledge of the patients regarding transmission of hepatitis $\mathrm{B}$ infection attending the
Gastroenterology Department of Medical College, Thiruvananthapuram.

\section{Data and Methodology}

State Board of Medical Research (SBMR) has approved the study procedures and funded the study. The respondents were outpatients in the Department of Medical Gastroenterology, Govt. Medical College, Thiruvananthapuram, Kerala during 2012.

\section{MATERIALS AND METHODS}

\section{Study Design}

It is a cross-sectional descriptive study. Patients are identified from the patients attending OP with HBsAg positive and 391 such cases are selected. Informed consent was taken from the respondents. Ethical clearance was made. The risks and benefits were explained and all the personal information of the study subjects was kept confidential. Demographic data included age, gender, marital status, education status, monthly family income, profession, type of house, residential status, knowledge about spread of Hepatitis B and route of transmission. The data is entered into an in-house computerised database. Univariate and multivariate analyses were conducted. The quantitative data is presented in frequency, percentage, mean and standard deviations. Data is analysed using chi-square test.

\section{Findings/ Socio-Economic and Demographic Background of the Patients}

Understanding socio-demographic characteristics of the patients is necessary for identifying the gaps in knowledge regarding hepatitis B. Age is an important demographic variable in acquiring knowledge. Table 1 shows that about 20 percent of the patients are aged 30 or less than it, more than one-fourth of the patients are in the age group of 31 - 40 years and highest percent are in the age group of 41 - 50 years (about 30 percent). Mean age of the patients is 42.3 years with standard deviation of 13.4 at $95 \%$ confidence interval. Among the patients, more than 72 percent are males. As resemblance to the general population of Kerala, Hindus form 61 percent of the respondent population and about 19 percent are Christians and about 20 percent are Muslims. Among respondents, 8.7 percent belong to SC/ST and about 21.5 percent belong to forward castes. More than half of the patients belonging to $\mathrm{OBC}$ group. Place of residence of the total respondents shows that about 25 percent belonging to urban and 68.5 percent belonging to rural and another 6.4 percent are from coastal areas. Type of house they live is the only variable to show the status of their living. Houses are classified as pucca, semi-pucca and kutcha according to their own perception. It shows that about 42 percent belong to pucca house and 34.5 percent reported their house as semi-pucca. While more than 68 percent of the control group reported their houses as pucca and more than one-fifth of the HBV patients reported they are in the lower socioeconomic strata. Educational analysis of the patient shows that only 2.6 percent are professionally educated and 10 percent are graduated and about 40 percent are high school educated. Occupational analysis reveals that about an equal percent (about 13 percent) of the respondents are distributed in service categories, such as professional and semi-professional and clerical. Percent of unskilled worker is also same. Patients of 
all occupational groups utilise government facilities, especially super speciality in the Medical Colleges.

\begin{tabular}{|c|c|c|}
\hline \multicolumn{2}{|c|}{ Characteristics } & Percent \\
\hline \multirow{7}{*}{ Age } & $\leq 20$ & 3.1 \\
\hline & $21-30$ & 17.6 \\
\hline & $31-40$ & 25.6 \\
\hline & $41-50$ & 30.2 \\
\hline & $51-60$ & 16.6 \\
\hline & $61-70$ & 3.3 \\
\hline & $>70$ & 3.6 \\
\hline \multirow{2}{*}{ Sex } & Male & 72.6 \\
\hline & Female & 27.4 \\
\hline \multirow{3}{*}{ Religion } & Hindu & 61.1 \\
\hline & Muslim & 19.9 \\
\hline & Christian & 18.9 \\
\hline \multirow{4}{*}{ Caste } & SC/ST & 8.7 \\
\hline & OBC/OEC & 52.2 \\
\hline & Forward & 21.5 \\
\hline & Others & 17.6 \\
\hline \multirow{3}{*}{ Residence } & Urban & 25.1 \\
\hline & Rural & 68.5 \\
\hline & Coastal & 6.4 \\
\hline \multirow{3}{*}{ Type of House } & Pucca & 41.9 \\
\hline & Semi Pucca & 34.5 \\
\hline & Kutcha & 23.5 \\
\hline \multirow{7}{*}{ Education } & Professional & 2.6 \\
\hline & Graduation & 10.2 \\
\hline & Intermediate & 18.7 \\
\hline & High school & 39.4 \\
\hline & Middle school & 19.7 \\
\hline & Primary & 7.7 \\
\hline & Illiterate & 1.8 \\
\hline \multirow{7}{*}{ Occupation } & Professional & 13.0 \\
\hline & Semi professional & 11.3 \\
\hline & Clerical & 12.5 \\
\hline & Skilled Worker & 16.1 \\
\hline & Semi-skilled worker & 18.2 \\
\hline & Unskilled worker & 12.3 \\
\hline & Unemployed & 16.6 \\
\hline
\end{tabular}

\section{General Awareness Regarding Hepatitis B}

Knowledge is an important tool in limiting transmission of any disease. Hepatitis B is highly infective. To prevent the transmission of Hepatitis B, proper knowledge regarding the viral infection and transmission is necessary. Hence, we attempted to find out awareness regarding the disease among the patients. Table 2 reveals general awareness about HBV. When enquired whether they heard about Hepatitis B, about 41 percent of the patients answered 'No.'

\begin{tabular}{|c|c|c|}
\hline \multicolumn{2}{|c|}{ Characteristics } & Percent \\
\hline Heard about & Yes & 59.1 \\
\cline { 2 - 3 } Hepatitis B & No & 40.9 \\
\hline \multirow{4}{*}{$\begin{array}{c}\text { Source of } \\
\text { Knowledge }\end{array}$} & TV & 7.8 \\
\cline { 2 - 3 } & Newspaper/Radio & 16.0 \\
\cline { 2 - 3 } & Relatives & 18.6 \\
\cline { 2 - 3 } & Friends & 9.5 \\
\cline { 2 - 3 } & $\begin{array}{c}\text { Relatives, friends and health } \\
\text { workers together }\end{array}$ & 15.2 \\
\cline { 2 - 3 } & Media only & 6.5 \\
\hline
\end{tabular}

\begin{tabular}{|c|c|c|}
\hline & $\begin{array}{l}\text { Both media and relative } \\
\text { group }\end{array}$ & 3.0 \\
\hline & Total & $231(59.1)$ \\
\hline Knowledge & Yes & 48.3 \\
\hline $\begin{array}{l}\text { about the Urgan } \\
\text { Affected }\end{array}$ & No & 51.7 \\
\hline & Heart & 2.1 \\
\hline & Lungs & 2.6 \\
\hline Oroan Affects & Liver & 93.7 \\
\hline Organ Afrects & Stomach & 0.5 \\
\hline & All organs & 1.1 \\
\hline & Total & $202(48.3)$ \\
\hline Knowledge about & Yes & 52.7 \\
\hline How to Spread & No & 47.3 \\
\hline & Correct Knowledge & 11.8 \\
\hline Route of & At least one correct & 27.1 \\
\hline Transmission & Misconception & 14.1 \\
\hline & Total & $207(52.9)$ \\
\hline Think Fatal & Fatal & 28.6 \\
\hline I mink Fatal & Curable & 71.4 \\
\hline Think Liver & Yes & 19.7 \\
\hline Cancer & No & 80.3 \\
\hline Immunisation & Yes & 0 \\
\hline Status & No & 100.0 \\
\hline Table 2. Gene & $\begin{array}{l}\text { 4wareness regarding } 1 \\
\text { ercent of Patients) }\end{array}$ & atitis $B$ \\
\hline
\end{tabular}

Those who answered 'Yes' reported that they were told by relatives (18.6 percent) and health care workers (15.2 percent). Radio or newspaper as source of knowledge is reported by 16 percent of the respondents and 8 percent reported TV as their source of knowledge. Whether they know the organ that the virus affects is enquired and it is only about 48 percent of the patients answered 'Yes.' Out of these patients, 94 percent knows that 'Liver' is the organ where the virus affects human body. Only 53 percent of the patients reported that they have the knowledge about how the virus spread from one person to another and out of these 11.8 percent have correct knowledge about its route of transmission. More than 70 percent reported that it is a curable disease and only 20 percent thought that it could lead to liver cancer.

Cross analysis of the socio-demographic variables with knowledge regarding hepatitis B is revealed in Table 3. Age is the important variable in acquiring any knowledge through education or through experience. Majority of the patients attending OP are adults and in higher age groups. Hence, the age group is divided to higher age groups. Table 3 reveals that less than 40 aged are more in number in hearing about HBV. Out of the 63 percent of the respondents in this age group, only 30 percent have heard it through media. Majority of the households in Kerala have a TV or radio and a newspaper. As we know there is no message (about hepatitis B) through media, Table 3 indicates that in all groups source of knowledge is mainly spread from other groups like friends, relatives or health workers, etc. The question 'do you know which organ is affected by Hepatitis B' is answered by only about half of the respondents. In sub-groups, it varies from 55 percent (skilled and semi-skilled category in occupational group) to 32 percent (primary and illiterate category in educational group). Knowledge about the organ, which the virus affects in the human body is correctly answered by majority of the respondents who answered the above question. None of the patients are immunised against Hepatitis B. 


\begin{tabular}{|c|c|c|c|c|c|}
\hline \multirow[t]{2}{*}{ 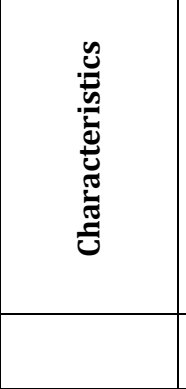 } & \multirow{2}{*}{ 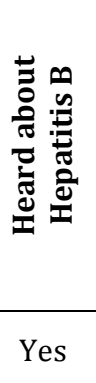 } & \multicolumn{2}{|c|}{ 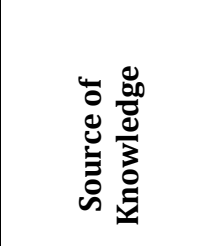 } & \multirow{2}{*}{ 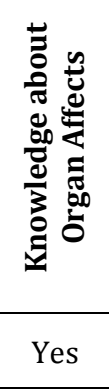 } & \multirow{2}{*}{ 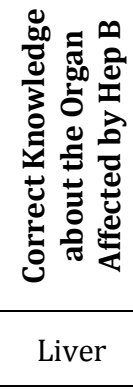 } \\
\hline & & $\begin{array}{c}\text { Media } \\
\text { Only }\end{array}$ & Others & & \\
\hline \multicolumn{6}{|c|}{ Age Group } \\
\hline$<40$ & 63.0 & $29.8^{* * *}$ & 70.2 & 49.7 & 91.1 \\
\hline $41-60$ & 58.5 & 33.6 & 66.4 & 49.2 & 95.6 \\
\hline$>61$ & 37.0 & 0 & 100 & 33.3 & 100 \\
\hline \multicolumn{6}{|c|}{ Sex } \\
\hline Male & 60.2 & 27.5 & 72.5 & 51.1 & 93.1 \\
\hline Female & 56.1 & 38.3 & 61.7 & 41.1 & 95.5 \\
\hline \multicolumn{6}{|c|}{ Education } \\
\hline $\begin{array}{c}\text { Professional } \\
\text { and } \\
\text { Graduation }\end{array}$ & 52.0 & 19.2 & 80.8 & 48.0 & 100.0 \\
\hline $\begin{array}{c}\text { Middle, High } \\
\text { and } \\
\text { Intermediate } \\
\text { Schooling } \\
\end{array}$ & 60.5 & 31.0 & 69.0 & 50.3 & 92.2 \\
\hline $\begin{array}{c}\text { Primary and } \\
\text { Illiterate }\end{array}$ & 56.8 & 38.1 & 61.9 & 32.4 & 100.0 \\
\hline \multicolumn{6}{|c|}{ Occupation } \\
\hline $\begin{array}{l}\text { Service } \\
\text { Category }\end{array}$ & 46.5 & 40.3 & 59.7 & 38.9 & 92.9 \\
\hline $\begin{array}{c}\text { Skilled and } \\
\text { Semi-Skilled } \\
\text { Workers }\end{array}$ & 64.9 & 20.7 & 79.3 & 55.2 & 91.9 \\
\hline $\begin{array}{c}\text { Unskilled } \\
\text { and } \\
\text { Unemployed }\end{array}$ & 68.1 & 32.5 & 67.5 & 52.2 & 96.6 \\
\hline \multicolumn{6}{|c|}{ Religion } \\
\hline Hindu & 55.2 & 30.3 & 69.7 & 45.2 & 94.4 \\
\hline Christian & 66.2 & 18.4 & 81.6 & 51.4 & 90.7 \\
\hline Muslim & 64.1 & 42.0 & 58.0 & 55.1 & 94.7 \\
\hline \multicolumn{6}{|c|}{ Residential Area } \\
\hline Urban & 62.2 & 29.5 & 70.5 & 50.0 & 100.0 \\
\hline Rural & 56.7 & 34.2 & 65.8 & 47.8 & 90.6 \\
\hline Coastal & 72.0 & \begin{tabular}{l|l}
0 \\
\end{tabular} & 100 & 48.0 & 100.0 \\
\hline \multicolumn{6}{|c|}{ Type of House } \\
\hline Pucca & 62.8 & 33.0 & 67.0 & $54.3^{* *}$ & 95.5 \\
\hline Semi-Pucca & 62.2 & 21.4 & 78.6 & 48.9 & 93.9 \\
\hline Kutcha & 47.8 & 40.9 & 59.1 & 37.0 & 88.2 \\
\hline $\begin{array}{r}\text { Table 3. Soci } \\
\end{array}$ & $\begin{array}{l}\text { o-Demo } \\
\text { Knowle }\end{array}$ & $\begin{array}{l}\text { graphic } \\
\text { dge (PeI }\end{array}$ & $\begin{array}{l}\text { cCharac } \\
\text { rcent Di }\end{array}$ & $\begin{array}{l}\text { eristics } \\
\text { ribution }\end{array}$ & atients $b$ \\
\hline
\end{tabular}

\section{Knowledge about Route of Transmission of HBV}

Knowledge regarding route of transmission is essential in controlling the spreading of HBV among the population. The multiple answers are put together and categorised into three: All answers are incorrect, At least one correct answer and All the answers are correct. Majority of the sample population does not know the difference in transmission between Hepatitis A (which is mainly spread through water) and Hepatitis B. Knowledge regarding route of transmission of HBV is known to only few of the respondents. Knowledge of at least one correct way of transmission is only for 39 percent of the patients. It means lack of knowledge about correct route of transmission is evident among patients.

\begin{tabular}{|c|c|c|c|c|c|}
\hline \multirow[b]{2}{*}{ 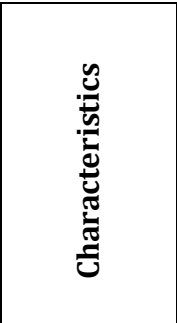 } & \multicolumn{3}{|c|}{$\begin{array}{c}\text { Knowledge about Route of } \\
\text { Transmission }\end{array}$} & \multirow{2}{*}{ 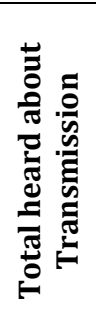 } & \multirow[b]{2}{*}{ : } \\
\hline & 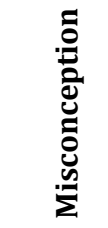 & 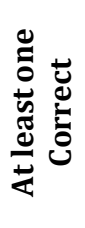 & $\begin{array}{l}\stackrel{0}{0} \\
\frac{0}{0} \\
\frac{0}{3} \\
0 \\
\vdots\end{array}$ & & \\
\hline \multicolumn{4}{|c|}{ Age Group } & & \\
\hline$<40$ & 23.5 & 52.9 & 23.5 & 49.3 & 102 \\
\hline $41-60$ & 27.8 & 51.5 & 20.6 & 46.9 & 97 \\
\hline$>61$ & 50.0 & 25.0 & 25.0 & 3.9 & 8 \\
\hline \multicolumn{4}{|c|}{ Sex } & & \\
\hline Male & 25.0 & 50.6 & 24.4 & 75.4 & 156 \\
\hline Female & 31.4 & 52.9 & 15.7 & 24.6 & 51 \\
\hline \multicolumn{4}{|c|}{ Education } & & \\
\hline \begin{tabular}{|c|} 
Professional \\
and \\
Graduation \\
\end{tabular} & 25.0 & 57.1 & 17.9 & 13.5 & 28 \\
\hline \begin{tabular}{|c|} 
Middle, High \\
and \\
Intermediate \\
Schooling \\
\end{tabular} & 26.4 & 51.5 & 22.1 & 78.7 & 163 \\
\hline \begin{tabular}{|c|} 
Primary and \\
Illiterate \\
\end{tabular} & 31.3 & 37.5 & 31.3 & 7.7 & 16 \\
\hline \multicolumn{4}{|c|}{ Occupation* } & & \\
\hline $\begin{array}{l}\text { Service } \\
\text { Category }\end{array}$ & 34.4 & 29.5 & 36.1 & 29.5 & 61 \\
\hline \begin{tabular}{|c|} 
Skilled and \\
Semi-Skilled \\
Workers \\
\end{tabular} & 16.5 & 59.5 & 24.1 & 38.1 & 79 \\
\hline \begin{tabular}{|c|} 
Unskilled \\
and \\
Unemployed
\end{tabular} & 31.3 & 61.2 & 7.5 & 32.4 & 67 \\
\hline \multicolumn{4}{|c|}{ Religion } & & \\
\hline Hindu & 26.4 & 47.9 & 25.6 & 58.5 & 121 \\
\hline Christian & 18.4 & 55.3 & 26.3 & 18.4 & 38 \\
\hline Muslim & 33.3 & 56.3 & 10.4 & 23.2 & 48 \\
\hline \multicolumn{4}{|c|}{ Area of Residence } & & \\
\hline Urban & 34.0 & 50.0 & 16.0 & 24.2 & 50 \\
\hline Rural & 24.0 & 50.0 & 26.0 & 70.5 & 146 \\
\hline \multirow[t]{2}{*}{ Coastal } & 27.3 & 72.7 & 0 & 5.3 & 11 \\
\hline & \multicolumn{5}{|c|}{ Type of Residence* } \\
\hline Pucca & 25.0 & 53.1 & 21.9 & 46.4 & 96 \\
\hline Semi-Pucca & 31.6 & 56.6 & 11.8 & 36.7 & 76 \\
\hline Kutcha & 20.0 & 34.3 & 45.7 & 16.9 & 35 \\
\hline $\begin{array}{r}\text { Table 4. Pe } \\
\text { Kno }\end{array}$ & $\begin{array}{l}\text { cent Dis } \\
\text { wledge }\end{array}$ & $\begin{array}{l}\text { ution } \\
\text { It Rou }\end{array}$ & $\begin{array}{l}\text { Responc } \\
\text { fTrans }\end{array}$ & $\begin{array}{l}\text { its rego } \\
\text { ission }\end{array}$ & ling \\
\hline
\end{tabular}

Table 4 reveals that correct knowledge is given by a small percentage. Out of the 49 percent who answered 'Yes,' knowledge of how Hepatitis B spreads is 24 percent in youngest age group. Misconception is more among the oldest age group. Only 30 percent had answered affirmatively, out of which 25 percent answered correctly regarding route of transmission. Gender differential is high in the sense that 75 percent of the male and 25 percent of female had answered 'Yes,' out of which only 15.7 percent of female and 24.4 percent of male knew correct route of transmission. More than 24 percent of the urban and 70 percent of the rural claimed that they know about the route of transmission. Out of these, 26 percent of the rural patients and 16 percent of the urban answered correctly and none of the respondents belonging to 
coastal areas answered correctly. Patients belonging to Muslim religion, primary and illiterate and unemployed category has a lower percent in providing correct knowledge on route of transmission. Percent of patients who claimed that they know the route of transmission belonging to pucca houses is 46 and that of kutcha houses is 17 percent. Out of these, 22 percent belonging to pucca houses and 46 percent of the patients belonging to kutcha houses answered correctly. A significant association at $\mathrm{p}<0.001$ is found among occupation and type of house with the correct knowledge on route of transmission in the above analysis.

\section{DISCUSSION}

The study has elucidated knowledge regarding HBV infection by analysing data of 391 patients attending OP unit in Govt. Medical College, Thiruvananthapuram, Kerala during 2012 2014. Asymptomatic individuals referred to the unit from other peripheral hospitals or clinics during the study period and who tested positive for Hepatitis B surface (HBsAg) are the respondents.

In the study it is revealed that about 59 percent heard about hepatitis $B$. When enquired about whether they know about organ affected by the HBV virus, only 48 percent answered 'Yes,' out of these 94 percent answered correctly. When enquired about whether they know about how to spread the virus, about 53 percent answered 'Yes.' Out of these only 12 percent answered correctly. Route of transmission of Hepatitis A is given as the answer of route of transmission of Hepatitis B according to the majority of the respondents.

It is evident from the analysis that even the highly educated and professionally occupied category does not know the correct route of transmission of the virus. Even though, majority of the households in Kerala has TV/ radio in their house and has a habit of reading newspaper daily, majority of the respondents are not reporting media as a source of knowledge. Media is giving more importance to HIV, but HBV which is more dangerous and more infectious than HIV is being neglected. Health providers and Government should take necessary steps in creating awareness regarding the HBV through media, so that people can easily get the message. Even the educated does not know the difference between hepatitis $\mathrm{A}$ and $\mathrm{B}$, and majority have not heard about other virus like Hepatitis C. It can be concluded from the study that there exists disparity in educational group regarding knowledge on HBV, which should be addressed for prevention activities. Such findings are in line with other Indian studies. Singh and Jain (2011 $^{[8]}$ reported that there is lack of awareness regarding Hepatitis B, its route of transmission and modes of prevention even among the medical students and only 87 percent of them had correct knowledge.

None of the respondents are immunised against the most infective virus. Since the disease is highly infective, but preventable, awareness and prevention are factors of importance. Transmission results from exposure to so many factors like infectious secretions, needles, unprotected sexual contacts and vertical transmission from mother to child during child birth etc. The importance of the stressing vaccination against Hepatitis B is evident from the study. Moreover, due to the costly treatment of Hepatitis B infection and lifethreatening complications, the preventive aspect is most important in combating the infection that should include creating awareness, early diagnosis and immunisation, and compliance with universal precautions.

\section{Limitations}

It is a hospital-based study and hence community wide inferences cannot be made. There is a paucity of populationbased epidemiological information regarding hepatitis $B$ virus (HBV) infection in India and Kerala is no exception. Hence, a community-based epidemiological study regarding knowledge about such infections is needed, which may guide how to prevent the viruses most effectively.

\section{CONCLUSION}

Even the educated do not know the difference between Hepatitis A and B, and majority have not heard about other viruses like Hepatitis C. It can be concluded from the study that there exists disparity in educational group regarding knowledge on HBV which should be addressed for prevention activities, especially through media. The importance of the stressing vaccination against Hepatitis $B$ is evident from the study.

\section{REFERENCES}

[1] WHO 2008. Hepatitis B-1. WHO Fact sheet, No. 204, World Health Organization, Geneva, 2008. http://www.who.int/mediacentre/factsheets/fs204/e n/index.html.

[2] Lavanchy D. Hepatitis B virus epidemiology, disease burden, treatment and current and emerging prevention and control measures. J Viral hepatitis 2004;11(2):97-107.

[3] Ganem D, Prince AM. Hepatitis B virus infection -natural history and clinical consequences. N Engl J Med 2004;350(11):1118-29.

[4] Kurien T, Thyagarajan SP, Jeyaseelan L, et al. Community prevalence of hepatitis b infection \& modes of transmission in Tamil Nadu, India. Indian Journal of Medical Research 2005;121(5):670-5.

[5] Jayaprakash PA, Shanmugam J, Hariprasad D. Hepatitis B surface antigen in blood donors. Transfusion 1983;23(4):346-7.

[6] Sandesh K, Varghese T, Harikumar R, et al. Prevalence of hepatitis Band C in the normal population and high risk groups in north Kerala. Trop Gastroenterol 2006;27(2):80-3.

[7] Afzal S, Bashir M. Determinants for transmission of Hepatitis B and C. Annals of King Edward Medical University 2009;15:4.

[8] Singh A, Jain S. Prevention of Hepatitis B: knowledge and practices among medical students. Healthline 2011;2(2):8-11. 